\title{
KEPAHAMAN DAN KESIAPAN MAHASISWA ATAS PENGGUNAAN TEKNOLOGI INFORMASI DALAM SISTEM INFORMASI AKUNTANSI TERHADAP KUALITAS INFORMASI AKUNTANSI DENGAN ETIKA SEBAGAI MODERATING VARIABLE
}

\author{
Ahmad Hafidh Agustin ${ }^{1)}$, Merlyana Dwinda Yanthi ${ }^{2)}$ \\ ${ }^{1)}$ Fakultas Ekonomi dan Bisnis \\ Universitas Negeri Surabaya \\ Jl. Lidah Wetan Lakarsantri Surabaya \\ ${ }^{2)}$ Fakultas Ekonomi dan Bisnis \\ Universitas Negeri Surabaya \\ Jl. Lidah Wetan Lakarsantri Surabaya
}

e-mail: ahmadhafidhagustin19@gmail.com ${ }^{1)}$, merlyanayanthi@unesa.ac.id ${ }^{2)}$

\begin{abstract}
ABSTRAK
Penelitian ini bertujuan untuk mendapatkan bukti empiris mengenai persepsi mahasiwa tentang pemahaman dan kesiapan mereka sebagai pengguna teknologi infomasi dalam sistem informasi akuntansi terhadap kualitas informasi. Penelitian berikut dilakukan untuk memperoleh bukti empiris pengaruh aspek etika dalam penggunaan teknologi informasi terhadap kualitas informasi. Purposive sampling dipilih sebagai metode pengumpulan data dari responden mahasiswa S1 akuntansi. Dari keseluruhan populasi dijadikan sampel sebanyak 75 responden. Data dianalisis menggunakan analisis statistik SPSS dengan teknik uji deskriptif, uji multikolinearitas, uji heterokedastisitas, uji asumsi klasik, dan uji nilai selisih mutlak. Hasilnya kepahaman dan kesiapan pengguna teknologi informasi dalam sistem informasi akuntansi berpengaruh terhadap kualitas informasi akuntansi dan etika pengguna menjadi variabel moderasi yang memperkuat pengaruh tersebut.
\end{abstract}

Kata kunci: etika, kepahaman dan kesiapan, kualitas informasi akuntansi, sistem informasi akuntansi

\begin{abstract}
This study aims to obtain empirical evidence regarding students' perceptions of their understanding and readiness as users of information technology in accounting information systems on information quality. Also, the following research was conducted to obtain empirical evidence of the influence of ethical aspects in the use of information technology on information quality. Purposive sampling was chosen as a method of collecting data from the respondents of undergraduate accounting students. Of the total population, 75 respondents were sampled. Data were analyzed using SPSS statistical analysis with descriptive test technique, multicollinearity test, heteroscedasticity test, classical assumption test, and absolute difference value test. The result is that the understanding and readiness of information technology users in the accounting information system affects the quality of accounting information and user ethics becomes a moderating variable that strengthens this influence.
\end{abstract}

Keywords: ethics, understanding and readiness, quality of accounting information, accounting information systems

\section{Pendahuluan}

Secara umum teknologi informasi merupakan penerapan teknologi yang digunakan untuk menyelesaikan permasalahan bisnis ataupun organisasi dalam skala besar atau kecil (Slyter, 2019). Teknologi informasi juga sebagai penggunaan komputer, penggunaan jaringan, dan perangkat lainnya sebagai infrastruktur dan proses untuk membuat, menjalankan, menyimpan, mengamankan, dan menukar segala bentuk data elektronik (Sabin et al., 2015). Pemanfaatan teknologi informasi saat ini digunakan sebagai penunjang sektor kehidupan masyarakat. Pemanfaatan teknologi informasi juga 
digunakan pada bidang akuntansi. Implementasi dari pemanfaatan teknologi informasi terwujud dalam penggunaan Sistem Informasi Akuntansi (SIA) untuk memanajemen sebuah informasi akuntansi.

Fungsi dari SIA untuk mengolah data akuntansi dari berbagai sumber menjadi informasi akuntansi yang diperlukan pemakai informasi untuk mengurangi resiko saat pengambilan keputusan (Susanto, 2017). SIA akan berjalan dengan baik saat pengguna sistem informasi tersebut memiliki sikap yang bijak. Sikap disini dapat dilihat dari etika seorang akuntan pada saat menggunakan sistem informasi akuntansi tersebut. Sejalan dengan ungkapan yang dikemukakan (Hati, 2017), penggunaan teknologi untuk menghasilkan informasi perlu mempertimbangkan aspek prilaku pengguna. Aspek pengguna yakni etika pengguna dalam menggunakan SIA. Etika merupakan pendekatan untuk memahami, menganalisis, dan membedakan masalah benar ataukah salah dan baik atau buruk (Rich \& Butts, 2013). Seperti halnya profesi yang profesional, profesi akuntan juga memiliki sebuah etika profesi yang melekat dalam kode etik profesi akuntansi.

Seorang akuntan yang memiliki pengetahuan cenderung kurang tentang SIA berbasis teknologi dan komputasi dapat tergeser posisinya akibat dari kemampuan jasa yang diberikan tidak sesuai dengan yang diinginkan klien atau perusahaan (Ardi, 2013). Maka sebagai pengguna yang menjalankan SIA, seorang akuntan tentunya perlu memahami dan memiliki kesiapan terhadap teknologi yang diimplementasikan dalam SIA. Pemahaman merupakan kemampuan seseorang menangkap makna dan arti dari hal yang telah dipelajari kemudian dinyatakan dengan mengubah data yang disajikan dalam bentuk tertentu ke bentuk yang lainnya (Sudaryono, 2012). Selain pemahaman, aspek kesiapan dari pengguna SIA juga menjadi penting adanya. Kesiapan merupakan kondisi seseorang ada pada tahap kematangan fisik, psikologis dan juga skill (Yusnawati, 2007). Tentunya kesiapan akan skill pengguna SIA menjadi hal yang perlu dimiliki pengguna.

Dari penelitian sebelumnya teknologi informasi dapat digunakan untuk penyajian data menjadi sebuah informasi secara reliable, real time, dan konsisten. Akan tetapi juga diperlukan pertimbangan aspek etika pengguna dalam memanfaatkan kemajuan teknologi informasi pada implementasi kerja SIA. Dengan kata lain kualitas sebuah informasi akuntansi juga tergantung pada etika penggunanya. Maka aspek etika pengguna menjadi sebuah variabel penting dalam penggunaan sistem informasi akuntansi. Penggunaan etika juga didasari permasalahan dalam lingkup profesi akuntansi. Beberapa waktu belakangan ada permasalahan yang menyangkut profesi akuntansi. Skandal keuangan yang menimpa organisasi bisnis ataupun instansi kerap dikaitkan dengan profesi pembuat informasi akuntansi tersebut. Seperti halnya KAP ternama pada tahun 2019 salah satunya KAP Purwanto, Sungkoro, dan Surja mendapatkan sanksi akibat melanggar kode etik profesi akuntan publik pada kasus penggelembungan pendapatan di laporan keuangan PT Hanson International Tbk 2016 (Wareza, 2019).

Penelitian ini mengangkat kerangka kerja penelitian kontijensi dengan tujuan melihat tingkat pemahaman dan kesiapan para pengguna SIA atas pengaruh perkembangan teknologi informasi terhadap sebuah informasi akuntansi yang berkualitas. Menggunakan variabel etika pengguna sistem informasi akuntansi sebagai variabel moderasi. Nantinya variabel moderasi ini kemungkinan dapat memperkuat, memperlemah, atau merubah hubungan varibel. Penelitian ini dimotivasi oleh penelitian (P. T. Sari \& Rohman, 2015) bahwa adanya hubungan yang berpengaruh antara teknologi informasi pada kualitas informasi akuntansi, (Awosejo, O.J, Kekwaletswe, R, M, Pretorius, P and Zuva, 2013) penggunaan sistem informasi akuntansi diterima oleh pengguna AIS, akan tetapi terdapat masalah adaptasi saat pengguna kurang mempersiapkan diri dengan perubahan teknologi, dan (Anggadini, 2019) etika pengguna berpengaruh terhadap keberhasilan SIA. Fokus penelitian untuk mengetahui kepahaman dan kesiapan pengguna teknologi informasi dalam SIA yang mempengaruhi kualitas sebuah informasi akuntansi. Dengan memperhatikan aspek etika pengguna SIA sebagai moderating variable. Penelitian ini akan memberikan manfaat untuk mahasiswa akuntansi mengetahui kompetensinya sebagai pengguna SIA untuk dapat bersaing di dunia kerja.

\section{Landasan Teori dan Pengembangan Hipotesis}

\subsection{Technology Acceptance Model (TAM)}

Teori TAM menjelaskan pengguna sebagai pengguna mengerti dan memahami dalam menggunakan teknologi informasi (Davis, 2013). Model dalam TAM menempatkan faktor sikap 
pengguna teknologi informasi menjadi penentu kemudahan penggunaan (ease of use) dan kemanfaatan (usefulness). Kedua variabel tersebut menjelaskan perilaku pengguna teknologi informasi (Davis, 2013). Variabel kemudahan dalam teori TAM memiliki skala item mudah untuk dipelajari, terkendali, jelas dan dapat dipahami, fleksibel, mudah menjadi terampil, dan mudah digunakan (Davis, 2013). Mahasiswa yang memiliki kepemahaman dan kesiapan dalam menggunakan sebuah teknologi informasi akan menghasilkan keterpecayaan dan minim risiko kesalahan. Perspektif kegunaan ini akan mempengaruhi sikap perilaku user (Davis, 2013). Penggunaan Technology Acceptance Model pada penelitian ini sebagai studi analisis persepsi pengaruh kepemahaman dan kesiapan mahasiswa sebagai pengguna teknologi informasi dalam SIA terhadap kualitas sebuah informasi akuntansi. Analisis khususnya pada karakteristik perceived ease of use/kemudahan penggunaan yang dirasakan, attitude/sikap, dan intentions/tujuan. Penggunaan TAM juga untuk melihat penggunaan nyata sebuah sistem informasi akuntansi yang berhubungan dengan etika pengguna.

\subsection{Teori Atribusi}

Teori atribusi mengartikan perilaku seseorang ditentukan oleh dua kombinasi kekuatan, yakni kekuatan internal (berasal dari faktor diri sendiri) dan kekuatan eksternal (berasal dari faktor luar diri seseorang) (Suartana, 2010). Teori atribusi menjelaskan penyebab perilaku orang lain maupun diri sendiri ditentukan oleh faktor internal seperti sifat, sikap, dan karakter orang tersebut atau ditentukan oleh faktor eksternal seperti situasi/keadaan tertentu yang dapat mempengaruhi perilaku individu (Luthans, 2005). Atribution Theory digunakan dalam penelitian ini dengan tujuan melakukan analisis pengaruh kepahaman dan kesiapan penggunaan teknologi informasi pada SIA terhadap kualitas informasi akuntansi dengan implementasi etika pengguna. Pengaruh karakteristik penggunaan teknologi informasi dan karakteristik personal pengguna yang berkaitan dengan etika dalam menghasilkan informasi akuntansi yang berkualitas.

\subsection{Pengaruh kepahaman dan kesiapan pengguna teknologi informasi dalam sistem informasi akuntansi terhadap kualitas informasi akuntansi}

Kepahaman dan kesiapan seseorang dapat mempengaruhi sikap orang tersebut dan mengarah pada perilaku tertentu dalam aktivitasnya. Azwar (2011) menyebutkan pengalaman pribadi seseorang dapat menjadi faktor yang dapat mempengaruhi sikap orang tersebut. Memiliki kepahaman dan kesiapan yang cukup terkait teknologi informasi akan mendorong sikap yang sesuai dengan pengguna teknologi informasi SIA yang sepatutnya. Dalam TAM terdapat kakarteristik yang menyertainya terkait teknologi informasi. Berkaitan dengan kemudahan penggunaan, sikap, dan tujuan. Sementara itu, letak dari kepahaman dan kesiapan pengguna disini menjadi faktor yang ingin dibuktikan bahwa faktor tersebut apakah dapat mempengaruhi keberhasilan penggunaan teknologi informasi dalam SIA dengan mengaitkannya pada karakteristik teori TAM.

Penelitian terdahulu (P. T. Sari \& Rohman, 2015) dan (Rahmi, 2013) menunjukkan teknologi informasi dapat meningkatkan kualitas informasi akuntansi. Dikombinasikan dengan kepahaman dan kesiapan pengguna, maka hipotesis yang dibangun kepahaman dan kesiapan pengguna teknologi informasi dalam SIA dapat mempengaruhi kualitas informasi akuntansi. Berdasarkan hipotesis yang dibangun, hipotesis yang digunakan yakni:

H1: Kepahaman dan Kesiapan Pengguna Teknologi Informasi dalam Sistem Informasi Akuntansi Berpengaruh Positif Terhadap Kualitas Informasi Akuntansi.

\subsection{Pengaruh kepahaman dan kesiapan pengguna teknologi informasi dalam sistem informasi akuntansi dengan etika pengguna terhadap kualitas informasi akuntansi}

Penggunaan teori atribusi akan memperkuat teori TAM pada aspek etika. Pada teori atribusi pengguna teknologi informasi dalam melakukan aktivitas akan dipengaruhi faktor baik dari internal dan eksternal, sehingga etika bisa mempengaruhi interaksi dari kepahaman dan kesiapan pengguna teknologi informasi terhadap kualitas informasi. Penelitian terdahulu mengungkapkan bahwa etika memiliki pengaruh terhadap pemanfaatan teknologi informasi. Audit yang berkualitas akan menjamin 
adanya profesi akuntan yang telah memenuhi tanggungjawabnya kepada pihak yang berkepentingan atas laporan keuangan dengan mengandalkan kredibilitasnya dan menegakkan etika (Widagdo, 2002). Juga penelitian terdahulu, etika pengguna memperkuat pengaruh teknologi informasi terhadap kualitas informasi akuntansi (P. T. Sari \& Rohman, 2015). Adapun penelitian terdahulu etika dapat memperlemah pengaruh kepahaman dan kesiapan pengguna teknologi informasi dalam SIA terhadap kualitas informasi akuntansi yaitu pengguna yang memiliki indikator etika yang bertentangan dengan prinsip etika profesional akuntansi cenderung akan melakukan perbuatan untuk berbuat tidak pada semestinya seperti melakukan facelift neraca dikarenakan tekanan dari atasan mereka (Morahan, 2015). Berdasarkan penjelasan dan pemikiran tersebut, hipotesis yang dibangun dalam penelitian ini:

H2: Etika Pengguna Dapat Memperkuat Pengaruh Kepahaman dan Kesiapan Pengguna Teknologi Informasi dalam SIA Terhadap Kualitas Informasi Akuntansi.

\section{Metode Penelitian}

Penelitian menggunakan data primer dengan teknik pengumpulan data secara kuisioner kepada responden mahasiswa perguruan tinggi jurusan akuntansi yang ada di kota Surabaya. Metode purposive sampling digunakan sebagai pertimbangan dalam pemilihan sampel dengan kriteria yakni mahasiswa jurusan akuntansi, status aktif masih menempuh pendidikan pada strata 1, dan mahasiswa strata 1 yang telah lulus menempuh mata kuliah sistem informasi akuntasi (SIA). Skenario pertanyaan untuk mengukur persepsi responden dengan lima skala likert. Penggunaan sampel mengacu Roscoe (1975) berpedoman pada rules of thumb yakni, sampel penelitian $30<n<500$. Penggunaan sampel juga mengacu Tabachnick \& Fidell (1996) dengan tujuan dapat melakukan analisis regresi. Menggunakan rumus $\mathrm{n} \geq 50+8(\mathrm{~m})$ dengan " $\mathrm{m}$ " sejumlah variabel independen. Berdasarkan kedua acuan tersebut, maka jumlah sampel yakni sejumlah 58 dari rumus Tabachnick 50+8(1). Jumlah tersebut juga memenuhi rumus sampel dari Roscoe dengan $30<\mathrm{n}<500$. Maka penggunaan sampel minimal dalam penelitian adalah 58. Dalam penelitian ini menggunakan 75 sampel dengan tujuan untuk mendapatkan response rate lebih dari 80 persen.

\subsection{Variabel Penelitian dan Definisi Operasional}

1. Kualitas Informasi Akuntansi (Y), merupakan keadaan sistem informasi tersebut memiliki arti bagi pengguna informasi, berupa fakta atau nilai yang memiliki manfaat (Bodnar \& Hopwood, 2000). Dalam penelitian ini pengguna adalah mahasiswa akuntansi. Variabel ini mengandung karakteristik dari kualitas informasi dalam laporan keuangan menurut (IAI, 2009). Variabel tersebut diukur dengan 3 indikator yakni kualitas informasi akuntansi dari (McGill et al., 2003), kepuasan pengguna (Doll \& Torkzadeh, 1988), dan dampak penggunaannya (Istianingsih \& Wijanto, 2008).

2. Kepahaman dan kesiapan pengguna (X), penelitian ini menggunakan variabel independen kepahaman dan kesiapan pengguna teknologi informasi. Kepahaman pengguna ditunjukkan dengan indikator mengerti dan memahami teknologi informasi. Mengerti teknologi informasi berarti telah dapat menangkap pengetahuan yang berkaitan dengan teknologi informasi itu sendiri. Sementara, memahami teknologi informasi berarti telah pandai atau dapat dikatakan mengerti benar akan teknologi informasi. Kesiapan pengguna ditunjukkan dengan indikator dapat mengoperasikan teknologi informasi yang diterapkan pada SIA. Variabel kepahaman diukur dengan pertanyaan penelitian terdahulu (staffnew uny, 2000) dan (R. Sari, 2008). Variabel kesiapan diukur dengan pertanyaan penelitian terdahulu (Narasinga, 2014).

3. Etika pengguna $(Z)$, berhubungan dengan seperangkat aturan, norma, dan pedoman berisi aturan perilaku yang perlu dilakukan ataupun ditinggalkan pada profesi dan dasar individu berperilaku terhadap sesamanya. Penelitian ini menggunakan variabel moderasi etika pengguna. Pengukuran atas variabel etika pengguna menggunakan Perceived Role of Ethics and Social Responsibility/PRESOR (Singhapakdi et al., 1996). Terdapat tiga dimensi didalamnya, yakni tanggungjawab sosial dan profitabilitas, keuntungan jangka panjang dan jangka pendek.

\subsection{Metode Analisis}

Metode penelitian ini adalah survei kuantitatif. Analisis dengan uji nilai selisih mutlak digunakan sebagai metode melakukan pengujian pengaruh interaksi dari variabel moderasi pada pengaruh 
variabel independen terhadap variabel dependenya (Rachmawati et al., 2015). Pengujian dilakukan setelah melakukan uji validitas dan realibilitas. Dilanjutkan melakukan uji asumsi klasik dengan tujuan model regresi terdistribusi normal dan terbebas dari gejala heterokedastisitas dan multikolinieritas. Model analisis uji nilai selisih mutlak sabagai berikut:

Keterangan:

$$
Y=a+b 1 X 1+b 2 Z+b 3|X 1-Z|+e
$$

Y : Kualitas Informasi Akuntansi (Y)

a : Konstansa

b : Koefisien regresi

$\mathrm{X} 1$ : Kepahaman dan kesiapan pengguna teknologi informasi

$\mathrm{Z}:$ Etika pengguna
$\mathrm{e}:$ Eror term

\section{Hasil dan Pembahasan}

\subsection{Uji Deskriptif}

Sampel yang digunakan dalam penelitian ini 75 responden. Variabel kepahaman dan kesiapan pengguna (X) terdiri atas beberapa indikator diantaranya mengerti teknologi informasi dan mengoperasikan teknologi infomasi. Pilihan tanggapan yang ada pada kuesioner dengan skala terkecil 1,00 dan terbesar 5,00. Tanggapan responden atas persepsi terhadap variabel kepahaman dan kesiapan pengguna sebesar 4,331111. Nilai tersebut masuk pada kategori setuju. Didapatkan kesimpulan responden setuju mengerti dan mampu mengoperasikan teknologi informasi dalam SIA akan lebih menghasilkan informasi yang berkualitas.

Tabel 1 Uji Deskriptif

\begin{tabular}{|l|l|l|l|}
\hline Variabel & Mean & Max & Min \\
\hline Kepahaman dan Kesiapan_X & 4,331111 & 5 & 1 \\
\hline Etika Pengguna_Z & 3,842500 & 5 & 1 \\
\hline Kualitas Informasi Akuntansi_Y & 4,014194 & 5 & 1 \\
\hline
\end{tabular}

Variabel etika pengguna $(Z)$ terdiri atas beberapa dimensi pengukuran, yakni tanggungjawab sosial dan profitabilitas, keuntungan jangka pendek, serta keuntungan jangka panjang. Pilihan tanggapan yang ada pada kuesioner dengan skala terkecil 1,00 dan terbesar 5,00. Tanggapan responden atas persepsi terhadap variabel kepahaman dan kesiapan pengguna sebesar 3,8425 . Nilai tersebut masuk pada kategori setuju. Didapatkan kesimpulan responden setuju bahwa etika pengguna mempengaruhi tanggungjawab sosial dan profitabilitas, keuntungan yang akan didapat pada jangka panjang serta jangka pendek.

Variabel kualitas informasi akuntansi (Y) terdiri atas indikator pengukuran, yakni kualitas informasi, kepuasan pengguna, dan dampak penggunaan. Pilihan tanggapan yang ada pada kuesioner dengan skala terkecil 1,00 dan terbesar 5,00. Tanggapan responden atas persepsi terhadap variabel kepahaman dan kesiapan pengguna sebesar 4,014194. Nilai tersebut masuk kategori setuju. Didapatkan kesimpulan responden setuju bahwa kualitas informasi akuntansi dihasilkan berasal dari terpenuhinya indikator informasi berkualitas, kepuasan pengguna, serta dampak yang dirasakan penggunanya.

\subsection{Uji Reliabilitas}

Hasil variabel Kepahaman dan Kesiapan Pengguna (X) memiliki nilai Cronbach's Alpha 0,757 atau 75,7\%, variabel Etika Pengguna (Z) memiliki nilai Cronbach Alpha 0,730 atau 73\%, dan variabel Kualitas Informasi Akuntansi (Y) memiliki nilai Cronbach Alpha 0,756 atau 75,6\%. Nilai ketiga variabel dalam penelitian ini $>0,60$. Sehingga dapat dikatakan variabel kepahaman dan kesiapan pengguna, etika pengguna, dan kualitas informasi akuntansi reliabel atau handal.

\subsection{Uji Validitas}

Uji validitas dilakukan menggunakan uji signifikansi yakni membandingkan nilai $\mathrm{r}$ hitung dengan nilai $r$ tabel degree of freedom $(d f)=n-2$ ( $\mathrm{n}$ yakni jumlah sampel). Didapatkan nilai $r$ tabel 
yang digunakan dengan jumlah sampel (n) sejumlah 75 dengan tingkat signifikasi 0,05 yakni: $\mathrm{r}(0,05$; $75-2=73)=0,2272$.

Tabel 2 Uji Validitas

\begin{tabular}{|c|c|c|c|c|c|c|c|c|}
\hline Item & $\begin{array}{l}\text { Item-Total } \\
\text { Correlation }\end{array}$ & Keterangan & Item & $\begin{array}{l}\text { Item-Total } \\
\text { Correlation }\end{array}$ & Keterangan & Item & $\begin{array}{l}\text { Item-Total } \\
\text { Correlation }\end{array}$ & Keterangan \\
\hline $\mathrm{X} 1$ & 0,748 & VALID & Z9 & 0,379 & VALID & Y13 & 0,666 & VALID \\
\hline $\mathrm{X} 2$ & 0,587 & VALID & $\mathrm{Z10}$ & 0,405 & VALID & Y14 & 0,752 & VALID \\
\hline $\mathrm{X} 3$ & 0,702 & VALID & Z11 & 0,524 & VALID & Y15 & 0,673 & VALID \\
\hline $\mathrm{X} 4$ & 0,525 & VALID & $\mathrm{Z12}$ & 0,419 & VALID & Y16 & 0,843 & VALID \\
\hline $\mathrm{X} 5$ & 0,512 & VALID & Z13 & 0,622 & VALID & Y17 & 0,790 & VALID \\
\hline X6 & 0,721 & VALID & Z14 & 0,608 & VALID & Y18 & 0,689 & VALID \\
\hline $\mathrm{X} 7$ & 0,757 & VALID & Z15 & 0,437 & VALID & Y19 & 0,759 & VALID \\
\hline $\mathrm{X} 8$ & 0,725 & VALID & Z16 & 0,617 & VALID & Y20 & 0,788 & VALID \\
\hline $\mathrm{X} 9$ & 0,610 & VALID & Y1 & 0,690 & VALID & Y21 & 0,787 & VALID \\
\hline $\mathrm{X} 10$ & 0,596 & VALID & $\mathrm{Y} 2$ & 0,697 & VALID & Y22 & 0,797 & VALID \\
\hline $\mathrm{X} 11$ & 0,664 & VALID & Y3 & 0,732 & VALID & Y23 & 0,439 & VALID \\
\hline $\mathrm{X} 12$ & 0,626 & VALID & Y4 & 0,766 & VALID & Y24 & 0,783 & VALID \\
\hline $\mathrm{Z1}$ & 0,394 & VALID & Y5 & 0,726 & VALID & Y25 & 0,856 & VALID \\
\hline $\mathrm{Z2}$ & 0,285 & VALID & Y6 & 0,601 & VALID & Y26 & 0,744 & VALID \\
\hline $\mathrm{Z3}$ & 0,580 & VALID & Y7 & 0,615 & VALID & Y27 & 0,748 & VALID \\
\hline $\mathrm{Z4}$ & 0,436 & VALID & Y8 & 0,437 & VALID & Y28 & 0,717 & VALID \\
\hline $\mathrm{Z5}$ & 0,623 & VALID & Y9 & 0,761 & VALID & Y29 & 0,758 & VALID \\
\hline Z6 & 0,438 & VALID & Y10 & 0,778 & VALID & Y30 & 0,681 & VALID \\
\hline $\mathrm{Z7}$ & 0,604 & VALID & Y11 & 0,657 & VALID & Y31 & 0,696 & VALID \\
\hline Z8 & 0,613 & VALID & Y12 & 0,407 & VALID & & & \\
\hline
\end{tabular}

Uji validitas pada pertanyaan kuesioner penelitian ini menunjukkan hasil keseluruhan pertanyaan dalam kuesioner pada variabel kepahaman dan kesiapan pengguna, etika pengguna, dan kualitas informasi akuntansi memiliki item-total correlation > 0,2272. Maka dapat dikatakan keseluruhan pertanyaan valid.

\subsection{Uji Asumsi Klasik}

Uji Normalitas : Hasil uji (1-sampel K-S) menunjukkan nilai signifikansi 0,200 yang dimana nilai tersebut lebih besar dari 0,05 . Maka, dapat disimpulkan data terdistribusi normal.

Uji Multikolinieritas : Model regresi terbebas dari multikolinearitas jika nilai tolerance $>0,10$ dan nilai $V I F<10,00$ pada hasil output data yang diolah. Hasil uji multikolineariltas pada model regresi penelitian ini menunjukkan nilai VIF variabel kepahaman dan kesiapan pengguna sebesar 1,264 dan variabel etika pengguna sebesar 1,264 atau kurang dari 10,00. Sementara nilai tolerance variabel kepahaman dan kesiapan pengguna serta variabel etika pengguna masing - masing sebesar 0,791 atau lebih dari 0.10. Dapat disimpulkan dengan hasil tersebut model regresi penelitian terbebas dari gejala multikolinearitas.

Uji Heterokedastisitas : Hasil uji glejser menunjukkan nilai signifikansi untuk variabel kepahaman dan kesiapan pengguna serta variabel etika pengguna masing - masing sebesar 0,137 dan 0,052 dengan kata lain lebih besar dari 0,05. Maka dapat disimpulkan tidak terjadi gejala heterokedastisitas.

\subsection{Uji t}

Tabel 3 Hasil Uji t Pada Selisih Nilai Mutlak

\begin{tabular}{|l|l|l|}
\hline \multirow{2}{*}{ Model } & Unstandardized Coefficients & \multirow{2}{*}{ Sig } \\
\cline { 2 - 3 } & B & 0,000 \\
\hline (Constant) & 121,707 & 0,000 \\
\hline Kepahaman dan Kesiapan Pengguna_X & 8,123 & 0,000 \\
\hline Etika Pengguna_Z & 7,191 & 0,039 \\
\hline Moderasi & 3,395 & \\
\hline
\end{tabular}


Pengujian hipotesis menunjukkan nilai probabilitas kesalahan variabel kepahaman dan kesiapan pengguna sebesar 0,000 dengan kata lain kurang dari 0,05. Dapat disimpulkan variabel kepahaman dan kesiapan pengguna berpengaruh terhadap kualitas informasi akuntansi. Memiliki pengaruh positif sebesar 8,123. Maka artinya, jika kepahaman dan kesiapan pengguna dalam menggunakan teknologi informasi pada SIA semakin baik akan berpengaruh pada kualitas informasi akuntansi yang semakin baik.

Pengujian pada variabel etika pengguna terhadap kualitas informasi akuntansi menjukkan nilai probabilitas kesalahan 0,000 dengan kata lain dibawah 0,05. Dapat disimpulkan variabel etika pengguna berpengaruh terhadap kualitas informasi akuntansi. Memiliki pengaruh positif sebesar 7,191. Maka artinya, jika etika pengguna semakin baik berpengaruh pada kualitas informasi akuntansi yang semakin baik.

Pengujian hipotesis moderasi menunjukkan nilai probabilitas kesalahan sebesar 0,039 dengan kata lain kurang dari 0,05. Dapat disimpulkan variabel etika pengguna memoderasi hubungan kepahaman dan kesiapan pengguna dengan kualitas informasi akuntansi. Memiliki koefisien sebesar 3,395. Dengan demikian variabel etika pengguna merupakan variabel moderasi yang memperkuat antara kepahaman dan kesiapan pengguna terhadap kualitas informasi akuntansi.

\subsection{Uji F}

Tabel 4 Hasil Uji F

\begin{tabular}{|l|l|l|l|}
\hline Model & df & F & Sig. \\
\hline Regression & 3 & 57,420 & 0,000 \\
\hline Residual & 71 & & \\
\hline Total & 74 & & \\
\hline
\end{tabular}

Menggunakan signifikan lima persen serta df1 $=2(3-1) \&$ df2 $=72(75-3)$ maka tabel F $(2 ; 72)$ $=3,12$. Perhitungan $F_{\text {hitung }}$ menunjukkan lebih besar dari $F_{\text {tabel }}$, yaitu 57,420 > 3,12. Nilai sig (probabilitas kesalahan) menunjukkan 0,000 dengan kata lain dibawah 0,05. Maka, artinya secara simultan dengan etika pengguna sebagai variabel yang memoderasi terdapat pengaruh kepahaman dan kesiapan pengguna terhadap kualitas informasi akuntansi.

\subsection{Uji Koefisien Determinasi $\left(\mathbf{R}^{2}\right)$}

Tabel 5 Hasil Uji R Square

\begin{tabular}{|l|l|l|}
\hline Model & $\mathrm{R}$ & $\mathrm{R}$ Square \\
\hline 1 & 0,842 & 0,708 \\
\hline
\end{tabular}

Pada analisis regresi uji selisih nilai mutlak menunjukkan nilai $R$ Square 0,708 atau $70,8 \%$. Disimpulkan 70,8\% variabel kepahaman dan kesiapan pengguna mempengaruhi kualitas informasi akuntansi dengan serta variabel etika pengguna sebagai variabel moderasi. Sedangkan sisanya 29,2\% $(100 \%-70,8 \%=29,2 \%)$ kualitas informasi akuntansi dipengaruhi variabel lain yang tidak ada pada penelitian ini.

\subsection{Pembahasan}

\section{A. Pengaruh Kepahaman dan Kesiapan Pengguna Teknologi Informasi Dalam Sistem Informasi Akuntansi Terhadap Kualitas Informasi Akuntansi}

Hasil uji t nilai signifikansi $0,000<0,05$ dengan koefisien positif 8,123 . Uji hipotesis dapat disimpulkan variabel kepahaman dan kesiapan pengguna memiliki pengaruh positif terhadap terbentuknya informasi akuntansi yang berkualitas. Hal ini menunjukkan bahwa pengguna teknologi informasi dalam SIA perlu memiliki kepahaman dan kesiapan yang baik bilamana ingin menghasilkan informasi akuntansi yang berkualitas. Hasil penelitian ini mendukung penelitian (P. T. Sari \& Rohman, 2015) dan (Rahmi, 2013) yang menjelaskan bahwa penggunaan teknologi informasi dapat meningkatkan kualitas sebuah informasi akuntansi. 
Sesuai dengan teori Technology Acceptance Model (TAM) yang menyatakan pengguna perlu mengerti dan memahami dalam memanfaatkan teknologi informasi. Maka, disini perlunya wawasan dan pengalaman dari mahasiswa akuntansi akan teknologi informasi sebagai pengguna SIA.

Mahasiswa akuntansi sebagai pengguna perlu memiliki pemahaman akan teknologi informasi dalam SIA yang berkaitan dengan mengerti dan memahami perkembangan perangkat software akuntansi terkini. Mahasiswa yang memiliki kepahaman teknologi informasi akan mampu melaksanakan tugas sebagai pengguna perangkat (software/hardware) akuntansi yang andal dan kredibel. Maka, informasi yang dihasilkan akan memiliki kriteria informasi akuntansi yang berkualitas. Sejatinya kualitas informasi penting bagi stakeholder dalam penentu kebijakan atas sebuah entitas.

Pengguna juga perlu untuk memiliki kesiapan yang berkaitan dengan mampu mengoperasikan perangkat teknologi informasi dalam SIA. Tujuannya untuk menyelaraskan antara ilmu pemahaman yang telah dimiliki dengan penerapannya pada tugas seorang akuntan profesional. Akuntansi profesional perlu memenuhi kuaifikasi dan memiliki sertifikasi yang sesuai dengan tugas dari jasa yang diberikan (Nyoman et al., 2015).

Berdasarkan uraian tersebut, maka terdapat pengaruh positif dari kepahaman dan kesiapan pengguna teknologi informasi dalam SIA terhadap kualitas informasi akuntansi. Semakin baik pemahan dan kesiapan pengguna dalam menguasai dan menjalankan teknologi informasi dalam SIA maka semakin baik pula kualitas informasi akuntansi yang dihasilkan.

\section{B. Pengaruh Kepahaman dan Kesiapan Pengguna Teknologi Informasi Dalam Sistem Informasi Akuntansi Dengan Etika Pengguna Sebagai Variabel Moderasi Terhadap Kualitas Informasi Akuntansi}

Hasil uji $\mathrm{t}$ nilai signifikansi $0,039<0,05$ dengan koefisien positif 3,395. Penelitian ini membuktikan secara empiris bahwa etika pengguna sebagai variabel moderasi yang memperkuat hubungan antara kepahaman dan kesiapan pengguna terhadap kualitas informasi akuntansi. Ditunjukkan dengan jalur koefisien bertanda positif. Hal ini mengindikasikan bahwa etika pengguna memiliki andil dalam terciptanya kualitas informasi akuntansi yang bermanfaat bagi penggunanya.

Dengan menerapkan etika yang sesuai, maka harapan besar informasi akuntansi yang dihasilkan akan berkualitas. Secara tidak langsung juga berdampak pada entitas yang memiliki tanggungjawab sosial dan profitabilitas entitas. Berdampak juga terhadap keuntungan jangka panjang dan jangka pendek dengan penerapan etika dalam lingkungan kerja entitas. Hasil penelitian ini mendukung penelitian Widagdo (2002) pengguna yang menegakkan etika dalam tugas seorang akuntan berarti telah menerapkan tanggungjawab sosial entitas pada informasi yang dihasilkan berupa laporan keuangan.

Sesuai dengan teori atribusi Luthans (2005), etika pengguna dapat terbentuk dari pengaruh orang lain dalam lingkungan kerja ataupun sifat, sikap, dan karakter akuntan itu sendiri. Sifat, sikap, dan karakter yang ada pada diri akuntan perlu dibina sedemikian rupa dalam upaya mencerminkan akuntan profesional yang beretika. Pengarahan dapat dilakukan dengan beberapa metode seperti pengembangan etika dan perilaku dalam aktivitas kerja. Melalui pembinaan mental ataupun training kontrol diri. Pengaruh eksternal juga dapat mempengaruhi etika akuntan seperti tekanan dari atasan. Untuk itu pentingnya pedoman tugas dan fungsi yang jelas dalam organisasi kerja dan pengawasan oleh audit internal melihat kesehatan interaksi lingkungan kerja. Maka disini pentingnya membangun lingkungan kerja akuntan yang berintegritas dan menjalankan etika sesuai kode etik seorang akuntan.

Berdasarkan uraian diatas, etika pengguna menjadi variabel pemoderasi yang memperkuat hubungan kepahaman dan kesiapan pengguna terhadap kualitas informasi akuntansi. Semakin kuat etika ditanamkan dan diterapkan oleh seorang akuntan maka akan memperkuat kinerja mereka. Dalam upaya menghasilkan informasi akuntansi yang berkualitas.

\section{Kesimpulan}

Berdasarkan pembahasan sebelumnya, dapat disimpulkan hipotesis diterima yaitu: Kepahaman dan kesiapan pengguna teknologi informasi dalam SIA berpengaruh dalam meningkatkan kualitas informasi akuntansi. Pengaruhnya positif dengan jalur koefisien bertanda positif. Hal ini mengindikasikan pentingnya kepahaman dan kesiapan yang perlu dimiliki pengguna teknologi 
informasi dalam SIA untuk dapat menghasilkan informasi akuntansi yang berkualitas. Hasil lainnya variabel etika pengguna menjadi variabel yang memoderasi hubungan anatara kepahaman dan kesiapan terhadap kualitas informasi akuntansi. Moderasi positif yang ditunjukkan dengan koefisian positif. Maka, pengguna teknologi informasi perlu untuk memahami dan sekaligus menerapkan etika yang semestinya dimiliki oleh akuntan profesional.

\section{Manfaat dan Saran}

Penelitian ini bermanfaat sebagai referensi untuk penelitian tentang pemahaman dan kesiapan pengguna teknologi informasi dalam menjalankan SIA terhadap kualitas informasi akuntansi. Saran untuk akuntan profesional perlu mengasah kemampuan mereka untuk dapat menguasai teknologi informasi dalam SIA. Kemampuan tersebut dapat dicapai dengan pelatihan atau sertifikasi khusus tentang implementasi penerapan teknologi informasi di dunia akuntansi. Variabel kepahaman dan kesiapan pengguna penting bagi penunjang akuntan untuk menjalankan teknologi informasi yang ada pada sistem informasi akuntansi serta etika seorang akuntan sebagai penguat menghasilkan informasi akuntansi yang berkualitas. Etika akuntan dapat dikendalikan baik dari diri akuntan dengan mentaati kode etik akuntan profesional dan upaya yang dilakukan oleh klien atau perusahaan untuk bersikap tidak mencampuri hak dan kewajiban akuntan yang dapat menjadi pelanggaran dalam hubungan tersebut. Diharapkan dengan kepahaman dan kesiapan pengguna teknologi informasi dalam sistem informasi yang optimal akan menghasilkan informasi akuntansi yang berkulitas dengan diikuti penerapan etika akuntan yang disiplin. Sehingga dapat berdampak bagi penentu kebijakan pihak terkait.

Batasan dalam penelitian ini adalah keterbatasan lokasi sampel dan tidak membandingkan pengguna sistem informasi akuntansi yang masih pada jenjang pendidikan dan pengguna pada jenjang karir. Untuk penelitian selanjutnya dapat menambah jumlah sampel dengan membandingkannya dengan pengguna sistem informasi akuntansi yang sudah pada karir sebagai akuntan profesional. Dengan tujuan mendapatkan hasil yang lebih spesifik.

\section{DAFTAR PUSTAKA}

Anggadini, S. (2019). Keberhasilan Sistem Informasi Akuntansi. 1, 58-74.

Ardi, B. K. (2013). Pengaruh Kemajuan Teknologi Informasi Terhadap Perkembangan Sistem Informasi Akuntansi. Dharma Ekonomi, 38, 1-12.

Awosejo, O.J, Kekwaletswe, R, M, Pretorius, P and Zuva, T. (2013). The Effect of Accounting Information Systems in Accounting. International Journal of Advanced Computer Research, $1(2), 21-31$.

Bodnar, G. H., \& Hopwood, W. A. (2000). Accounting Information System (A. A. Jusuf (ed.)). Salemba Empat.

Davis, F. D. (2013). Information Technology Introduction. 13(3), 319-340.

Doll, W. J., \& Torkzadeh, G. (1988). The Measurement of End-User Computing Satisfaction EndUser Satisfaction The Measurement of End-User Computing Satisfaction Professor of MIS and Strategic Management The University of Toledo Gholamreza Torkzadeh Assistant Professor of Information Systems. Source: MIS Quarterly, 1213512(2), 259-274. http://www.jstor.org/stable/248851\%0Ahttp://www.jstor.org/page/info/about/policies/terms.jsp \%0Ahttp://www.jstor.org

Hati, R. P. (2017). Pengaruh Efektifitas Penerapan Sistem Informasi Akuntansi, Pemanfaatan dan Kesesuaian Tugas pada Kinerja Pengurus Koperasi (Aktif dan Terdaftar di Dinas Koperasi dan Usaha Mikro). Measurement, 11(1), 1-10.

Istianingsih, I., \& Wijanto, S. H. (2008). Analisis Keberhasilan Penggunaan Perangkat Lunak Akuntansi Ditinjau Dari Persepsi Pemakai (Studi Implementasi Model Keberhasilan Sistem Informasi). Jurnal Akuntansi Dan Keuangan Indonesia, 5(1), 50-76. https://doi.org/10.21002/jaki.2008.03

Luthans, F. (2005). Organizational Behavior (S. Purwanti \& V. A. Yuwoni (eds.); 10th ed.). Penerbit Andi.

McGill, T., Hobbs, V., \& Klobas, J. (2003). User-developed applications and information systems 
success: A test of DeLone and McLean's model. Information Resources Management Journal, 16(1), 24-45. https://doi.org/10.4018/irmj.2003010103

Morahan, M. (2015). Ethics in management. IEEE Engineering Management Review, 43(4), 23-25. https://doi.org/10.1109/EMR.2015.7433683

Narasinga, D. D. (2014). PENGARUH PARTISIPASI PEMAKAI SISTEM INFORMASI, KEAHLIAN PEMAKAI SISTEM INFORMASI DAN PELATIHAN DAN PENDIDIKAN PEMAKAI SISTEM INFORMASI TERHADAP KINERJA SISTEM INFORMASI AKUNTANSI [Universitas Pasundan]. http://repository.unpas.ac.id/id/eprint/6441\%0A

Nyoman, N., Triani, A., \& Yanthi, M. D. (2015). Kesiapan Profesi Akuntan Di Indonesia Dalam Menghadapi Mea. Seminar Nasional Dan The 2nd Call for Syariah Paper, 612-625.

Rachmawati, D. I., Yuniarti, D., \& Nohe, D. A. (2015). Model Regresi Variabel Moderasi dengan Metode Selisih Mutlak. Jurnal Eksponensial, 6(2), 187-192.

Rahmi, M. (2013). PENGARUH PENGGUNAAN TEKNOLOGI INFORMASI DAN KEAHLIAN PEMAKAI TERHADAP KUALITAS INFORMASI AKUNTANSI. Jurnal Akuntansi, 25. http://ejournal.unp.ac.id/students/index.php/akt/article/view/634/393

Rich, K. L., \& Butts, J. B. (2013). Nursing Ethics (3rd ed.). Jones \& Bartlett Learning. https://books.google.co.id/books?hl=en\&lr=\&id=9R_ET0JLvEwC\&oi=fnd\&pg=PA3\&dq=Ethic s+is+karen+l+\&ots=fbD8HN7vYK\&sig=J6qRfhBRDxMH0H_OYYujrAf-

8_4\&redir_esc $=\mathrm{y} \# \mathrm{v}=$ onepage $\& \mathrm{q}=$ Ethics is karen $1 \& \mathrm{f}=$ false

Roscoe, J. T. (1975). Fundamental research statistics for the behavioural sciences (2nd ed.). Holt, Rinehart and Winston.

Sabin, M., Impagliazzo, J., Alrumaih, H., Byers, B., Gudoniene, D., Hamilton, M., Kotlyarov, V., Lunt, B., McGuffee, J. W., Peltsverger, S., Tang, C., Viola, B., \& Zhang, M. (2015). Multinational perspectives on information technology from academia and industry. ITiCSEWGP 2015 - Proceedings of the 2015 ITiCSE Conference on Working Group Reports, 149-171. https://doi.org/10.1145/2858796.2858802

Sari, P. T., \& Rohman, A. (2015). Persepsi Mahasiswa Atas Pengaruh Teknologi Informasi Terhadap Kualitas Informasi Akuntansi Dengan Etika Pengguna Sebagai Variabel Moderasi. Diponegoro Journal of Accounting, 4(2), 543-553.

Sari, R. (2008). IMPLIKASI TEKNOLOGI INFORMASI TERHADAP KUALITAS INFORMASI HAM DI BADAN PENELITIAN DAN PENGEMBANGAN HAK ASASI MANUSIA DEPARTEMEN HUKUM DAN HAM R.I. Uinversitas Indonesia.

Singhapakdi, A., Vitell, S. J., Rallapalli, K. C., \& Kraft, K. L. (1996). The perceived role of ethics and social responsibility: A scale development. Journal of Business Ethics, 15(11), 1131-1140. https://doi.org/10.1007/BF00412812

Slyter, K. (2019). What Is Information Technology? A Beginner's Guide to the World of IT. Rasmussen College. https://www.rasmussen.edu/degrees/technology/blog/what-is-informationtechnology/

staffnew uny. (2000). Konsep Teknologi Informasi Dan Komunikasi Bab. Konsep Teknologi Informasi Dan Komunikasi Bab, 3.

Suartana, I. W. (2010). Akuntansi keperilakuan Teori dan implementasi. Andi.

Sudaryono. (2012). Dasar-Dasar Evaluasi Pembelajaran. Graha Ilmu.

Susanto, A. (2017). Sistem Informasi Akuntansi - Pemahaman Konsep Secara Terpadu (1st ed.). Lingga Jaya.

Tabachnick, B. G., \& Fidell, L. S. (1996). Using multivariate statistics (3rd ed). HarperCollins College Publishers.

Wareza, M. (2019). Lagi-lagi KAP Kena Sanksi OJK, Kali Ini Partner EY. 09 Agustus 2019. https://www.cnbcindonesia.com/market/20190809100011-17-90855/lagi-lagi-kap-kena-sanksiojk-kali-ini-partner-ey

Widagdo, R. (2002). Analisis Pengaruh Atribut-Atribut Kualitas Audit Terhadap Kepuasan Klien (Studi Empiris Pada Perusahaan Yang Terdaftar di Bursa Efek Jakarta) [Universitas Diponegoro]. http://eprints.undip.ac.id/10719/

Yusnawati. (2007). Kesiapan berwirausaha siswa jurusan kecantikan SMKN. Universitas Negeri Yogyakarta. 